\title{
Teat disorders predispose ewes to clinical mastitis after challenge with Mannheimia haemolytica
}

\author{
Vasia S. MAVROGIANNI, Peter J. CRIPPS, Nikolaos PAPAIOANNOU, \\ Ioannis TAITZOGLOU, George C. FTHENAKIS* \\ Faculty of Veterinary Science, University of Thessaly, PO Box 199, 43100 Karditsa, Greece
}

(Received 20 January 2005; accepted 7 June 2005)

\begin{abstract}
In order to study the effects of sheep teat disorders on the protection of the mammary gland, we used a Mannheimia haemolytica isolate, which did not cause clinical mastitis when deposited into intact teats. In the first experiment, this was deposited into the duct of teats with orf (Group A, $n=5$ ) or papilloma (Group B, $n=3$ ). In the second, teats were chapped and then, the organism was deposited into the duct (Group C, $n=7$ ) or on the skin (Group D, $n=4$ ). Ewes with healthy teats were controls (Group E, deposition into duct, $n=5$; Group F, deposition on skin, $n=$ 2). The ewes in Groups A, B or C developed clinical mastitis $5 \mathrm{~h}$ later, whilst the ewes in Group D developed it $2 \mathrm{~d}$ later; no control ewe developed clinical mastitis. In ewes with teat lesions, the organism was isolated from secretion samples and the California Mastitis Test became positive $5 \mathrm{~h}$ after challenge; neutrophils and lymphocytes were seen in Giemsa-stained secretion films from Group A or B ewes, whilst macrophages, neutrophils and lymphocytes in films from Group C or D ewes; neutrophils were predominating in films from Group E or F ewes. Inside the teats of Group A, $\mathrm{B}, \mathrm{C}$ or D ewes, folds, hyperaemia and mucosal thickness were seen; histologically, subepithelial leucocytic infiltration was seen. In Group A or B ewes, no evidence of lymphoid tissue at the teat duct-cistern border was found. In Group C or D ewes, intense erosion and ulceration of the teat skin and conspicuous lymphoid tissue at the teat duct-cistern border, were evident; lesions characteristic of haemorrhagic mastitis were in the mammary parenchyma. In control ewes, subepithelial leucocytic infiltration in the teat duct and lymphoid tissue as above, were evident. We postulate that teat lesions can be predisposing factor to mastitis, by adversely affecting defences and speeding the process of infection and making it more severe.
\end{abstract}

mastitis / sheep / teat / predisposing factor / orf

\section{INTRODUCTION}

Ovine mastitis is a widespread disease of ewes with significant adverse production effects [7, 8]. The disease has not been studied as extensively as that in cows; consequently mechanisms of its pathogenesis have not been clarified and accurate control measures have not been proposed.
The teat is the most common portal of entry of the various causal agents. Furthermore, it is a part of the udder that is particularly influenced by external factors; in dairy ewes, hands of milkers or machine clusters apply a significant force to the teat, whilst in ewes of mutton breeds, the teat is subjected to licks and bites from lambs. Various defence mechanisms have been

\footnotetext{
* Corresponding author: gcf@ vet.uth.gr
} 
Table I. Summary of experimental design.

\begin{tabular}{lrc}
\hline Group* - teat lesions & Inoculation procedure & $\begin{array}{c}\text { Time-points when ewes were } \\
\text { euthanised, after challenge }\end{array}$ \\
\hline A $(n=5)$ - orf lesions & 1250 c.f.u. 2 mm-deep into the teat & $2 \mathrm{~h}, 5 \mathrm{~h}, 12 \mathrm{~h}, 1 \mathrm{~d}, 3 \mathrm{~d}$ \\
$\mathrm{~B}(n=3)$ - papilloma lesions & 1250 c.f.u. 2 mm-deep into the teat & $5 \mathrm{~h}, 1 \mathrm{~d}, 3 \mathrm{~d}$ \\
$\mathrm{C}(n=7)$ - chapping lesions & 1250 c.f.u. 2 mm-deep into the teat & $2 \mathrm{~h}, 5 \mathrm{~h}, 12 \mathrm{~h}, 1 \mathrm{~d}, 2 \mathrm{~d}, 3 \mathrm{~d}, 4 \mathrm{~d}$ \\
$\mathrm{D}(n=4)$ - chapping lesions & Immersion into broth-culture $\left(2 \times 10^{8}\right.$ c.f.u. $)$ & $1 \mathrm{~d}, 2 \mathrm{~d}, 3 \mathrm{~d}, 4 \mathrm{~d}$ \\
$\mathrm{E}(n=5)$ - clinically healthy & 1250 c.f.u. 2 mm-deep into the teat & $12 \mathrm{~h}, 1 \mathrm{~d}, 2 \mathrm{~d}, 3 \mathrm{~d}, 4 \mathrm{~d}$ \\
$\mathrm{~F}(n=2)$ - clinically healthy Immersion into broth-culture $\left(2 \times 10^{8}\right.$ c.f.u. $)$ & $2 \mathrm{~d}, 4 \mathrm{~d}$ \\
\hline
\end{tabular}

Challenge was carried out with $M$. haemolytica isolate VSM08L.

described in the teat of cows, e.g. the keratin lining in the teat duct, as well as leucocytes and non-specific antibacterial proteins in the teat cistern $[16,17,52,54,56,57,61]$, but such extensive studies have not been previously carried out in ewes.

In a previous paper [45], we described that clinically healthy teats of ewes provided significant protection against Mannheimia haemolytica intramammary infection. We found that the deposition of M. haemolytica into the teat duct did not result in clinical mastitis, although an inflammatory reaction had been elicited; direct inoculation of the same organisms into the gland cistern always resulted in clinical mastitis. During that study, we observed a focus of lymphoid tissue at the border between the teat ductteat cistern; we postulated that this structure might play a protective role, as in histological sections from teats inoculated with the organism, it was hyperplastic with germinal activity.

Sheep may also be used as models in experimental studies of bovine mastitis. Although there are differences between the two species, e.g. M. haemolytica is a very rare causal agent of bovine mastitis, whilst Escherichia coli an uncommon one for sheep mastitis, there are also similarities between them, e.g. milking is considered to be a factor facilitating the entrance of organisms into the teat. Hence, studies carried out in ewes may be of value in the study of the pathogenesis of the disease in cows.
The objectives of the work described in this paper were the following: (i) to study the effects of some ovine teat disorders, natural or experimentally inflicted, in the protection afforded by the teat in cases of $M$. haemolytica challenge and (ii) to describe the features of the resulting lesions.

\section{MATERIALS AND METHODS}

\subsection{Experimental design}

Two experiments were performed during this study. They were carried out under a licence for experimental procedures obtained from the Greek Ministry of Agriculture.

The animals were inoculated with an isolate of M. haemolytica (strain VSM08L), which had been isolated in three consecutive samplings, from the teat duct of a clinically healthy ewe in Greece. No abnormal clinical findings were present in the mammary gland of that animal, the California Mastitis Test (CMT) was negative and no bacteria were isolated from mammary secretion. The organism was recovered from the tip of a fine catheter $2 \mathrm{~mm}$-long, which had been inserted into the teat for sampling. The isolate was found to cause mastitis in ewes when inoculated directly into the gland cistern, whilst deposition into the duct or the cistern of clinically healthy teats resulted in only mild subclinical mastitis [45].

The experimental design is summarised in Table I and presented in detail below. 


\subsubsection{Experiment I: deposition of M. haemolytica into the teat duct of ewes with orf or papilloma virus}

Eight 3- to 5-year-old, Karagouniko-breed ewes, were used in the experiment. The animals selected, had viral lesions in their teats, Group A $(n=5)$ orf (contagious ecthyma) lesions and Group B $(n=3)$ papilloma lesions. This clinical diagnosis was confirmed by the results of a semi-nested PCR assay, using the primers PPP-1, PPP-4 and PPP-3, designed to amplify a part of the B2L gene of the virus [41]. Skin lesions were detected in the ewes 15 to 20 days after their lambing.

For selection, a thorough clinical examination was carried out in these ewes. Special attention was paid to their mammary glands, which were examined as described before [27], and teats. Each teat was held between the thumb and the index finger of the examiner (VSM) and palpated throughout its length; its shape, size and consistency were evaluated. The teats of the same ewe were compared to each other. Lesions present on each teat were described.

The skin around the teat orifice and in the lower lateral part (approx. $1 \mathrm{~cm}$ ) of the teat was swabbed by means of a sterile cottonswab moistened in Soy-broth. A sterile plastic fine catheter $2 \mathrm{~mm}$-long, was inserted into the teat and moved from the left to right, in order to sample the mucosa. Then, mammary secretion samples were obtained. The first two squirts of secretion were discarded and then, 10 to $15 \mathrm{~mL}$ of secretion were carefully collected into a sterile container.

All samples were cultured onto Columbia blood agar; the media were incubated aerobically at $37{ }^{\circ} \mathrm{C}$ for up to $72 \mathrm{~h}$. The CMT was carried out in secretion samples, as described before [28]; secretion films were made and stained by the Giemsa method.

Three days after examination (i.e. 18th to 23rd day of lactation), the lambs of these ewes were weaned and subsequently, the animals were hand-milked thrice daily. The ewes were examined again and the samples were collected as above, on the day of weaning of the lambs and on the day of inoculation.

Inoculation was performed four days after weaning of the lambs (i.e. $22 \mathrm{nd}$ to $27 \mathrm{th}$ day of lactation). For inoculation, the isolate was grown on Columbia blood agar and checked for purity; then it was inoculated into Soy-broth (BioMerieux, Marcy-l'-Étoile, France) and incubated aerobically at $37{ }^{\circ} \mathrm{C}$ for $5 \mathrm{~h}$. Serial dilutions of the broth culture into phosphate-buffer-saline (PBS), $\mathrm{pH}$ 7.3, were carried out; finally, $0.2 \mathrm{~mL}$ of the desired dilution was withdrawn with a syringe. The inoculum contained 1250 c.f.u., as estimated by the method of Miles and Misra [46]. To ensure sterile conditions, on the day before inoculation, the hairs of the teats were clipped using fine scissors and the skin of the udder and teats was scrubbed using chlorhexidine; then on the day of inoculation the teats were disinfected using an iodine povidone solution. The ewes were challenged as follows; a sterile plastic fine catheter (Abbocath, Abbott, Abbott Park, Illinois, USA) $20 \mathrm{G}, 2 \mathrm{~mm}$-long, was inserted into the teat; the syringe was attached to the catheter and the bacterial suspension was deposited inside the teat. The same technique was used to inject $0.2 \mathrm{~mL}$ of PBS into the other teat of each ewe, which was used as the control.

\subsubsection{Experiment II: deposition of M. haemolytica into the teat duct or the teat skin of the ewes, with artificially induced skin chapping}

Eleven primiparous Karagouniko-breed ewes were used. Immediately after lambing and every two days thereafter, a thorough clinical examination of these animals was carried out; special attention was paid to their mammary glands and teats. Furthermore, skin, intra-teat catheter and secretion samples were obtained for bacteriological and cytological examination, as described above. 
Table II. Classification of teat lesions scores and reactions after immersion into $1 \mathrm{~N} \mathrm{NaOH}$ solution [25].

\begin{tabular}{|c|c|}
\hline Score & Description of reaction \\
\hline 1 & Teat apparently normal, devoid of lesions, scabs and chaps \\
\hline 2 & $\begin{array}{l}\text { Less than half of the teat chapped, with few lesions present and much of the ulcerative tissue } \\
\text { covered with scabs or absent; areas of normal skin apparent; no sensitivity of the animal } \\
\text { to skin palpation }\end{array}$ \\
\hline 3 & $\begin{array}{l}\text { Half of the teat chapped, with areas of ulcerative lesions present and beginning of healing } \\
\text { as evidenced by formation of scabs and reduction of areas rough and raw }\end{array}$ \\
\hline 4 & $\begin{array}{l}\text { More than } 75 \% \text { of the teat chapped, with skin rough and raw and several ulcerative lesions } \\
\text { on the teat body; animal sensitive to teat palpation }\end{array}$ \\
\hline
\end{tabular}

The lambs of these ewes were weaned 18 days after lambing and subsequently, the animals were hand-milked thrice daily. Four days after weaning of the lambs (i.e. 22 nd day of lactation), the lower 3.0 to $3.5 \mathrm{~cm}$ of both teats of these ewes were immersed into a $1 \mathrm{~N}$ solution of $\mathrm{NaOH}$ for $1 \mathrm{~min}$; the procedure was repeated on the following day. The resulting chapping was scored according to the standards detailed in Table II [25].

One day later, the animals were divided into two groups and challenged as follows. Group C animals $(n=7)$ were inoculated using the technique described above; 1250 c.f.u. of the challenge isolate were deposited $2 \mathrm{~mm}$-deep into the teat duct of one of the teats, whilst $0.2 \mathrm{~mL}$ of PBS was injected into the other teat, which was used as the control. For ewes in Group D $(n=4)$, the whole broth culture was used; the ewes were completely milked out; three hours later, the lower $3 \mathrm{~cm}$ of the teat were immersed into $40 \mathrm{~mL}$ of the broth for $60 \mathrm{~s}$; after a 30 min break, they were re-immersed into the same broth culture. The procedure was repeated on the following day. By using the same procedure, the other teat of each ewe was immersed into $40 \mathrm{~mL}$ of sterile PBS.

\subsubsection{Controls}

Seven primiparous Karagouniko-breed ewes were used. Immediately after lambing and every two days thereafter, a thorough clinical examination was carried out in these; special attention was paid to their mammary glands and teats. Furthermore, skin, intra-teat catheter and secretion samples were obtained for bacteriological and cytological examination, as described above.

The lambs of these ewes were weaned 20 days after lambing and subsequently, the animals were hand-milked thrice daily. Four days after weaning of the lambs (i.e. 24th day of lactation), the animals were divided into two groups and challenged as follows: Group E animals ( $n=5)$ were inoculated using the technique described above; 1250 c.f.u. of the challenge isolate were deposited $2 \mathrm{~mm}$-deep into the teat duct of one of the teats, whilst $0.2 \mathrm{~mL}$ of PBS was injected into the other teat, which was used as the control. For ewes of Group F $(n=2)$, the whole broth culture was used; the procedure described above was employed and one teat was immersed into it, whilst the other was immersed into sterile PBS. The procedures carried out in these animals were identical to those of a larger study described before [45].

\subsection{Post-inoculation examinations}

Detailed general clinical examinations and examinations of the mammary glands and teats were carried out $2 \mathrm{~h}, 5 \mathrm{~h}, 12 \mathrm{~h}$, $18 \mathrm{~h}, 1 \mathrm{~d}, 2 \mathrm{~d}, 3 \mathrm{~d}$ and $4 \mathrm{~d}$ after challenge (unless of course, a ewe had been euthanised before that). In Group D or F ewes, 
sterile cotton-swabs moistened in Soy-broth were used to sample the skin around the teat orifice and the lower lateral part (approx. $1 \mathrm{~cm}$ ) of the teat before disinfection; and a sterile plastic fine catheter $2 \mathrm{~mm}$-long, was also inserted into the teat to sample the mucosa. Mammary secretion samples were collected from the animals of all groups. All samples were cultured onto Columbia blood agar; the media were incubated aerobically at $37^{\circ} \mathrm{C}$ for up to $72 \mathrm{~h}$.

The CMT was carried out in all secretion samples. Secretion films, made by directly smearing $20 \mu \mathrm{L}$ from each sample on a microscope objective plate, were stained by the Giemsa method; the percentage of leucocyte subpopulations was determined by counting at least 200 cells therein and distinguishing their type.

The ewes were euthanised as follows; the ewes in Group A: 2 h, 5 h, 12 h, 1 d, 3 d after challenge, the ewes in Group B: $5 \mathrm{~h}$, $1 \mathrm{~d}, 3 \mathrm{~d}$ after challenge, the ewes in Group C: $2 \mathrm{~h}, 5 \mathrm{~h}, 12 \mathrm{~h}, 1 \mathrm{~d}, 2 \mathrm{~d}, 3 \mathrm{~d}, 4 \mathrm{~d}$ after challenge, the ewes in Group D: $1 \mathrm{~d}, 2 \mathrm{~d}, 3 \mathrm{~d}, 4 \mathrm{~d}$ after challenge, the ewes in Group E: $12 \mathrm{~h}, 1 \mathrm{~d}$, $2 \mathrm{~d}, 3 \mathrm{~d}, 4 \mathrm{~d}$ after challenge, the ewes in Group F: 2 d, 4 d after challenge. Dissection of the mammary glands and the teats started immediately and was carried out using the aseptic technique. The skin of the teats and the subcutaneous tissues were incised with a sterile blade. Initially the mucosa of the teat cistern (sinus papillaris) was exposed and subsequently the teat duct (ductus papillaris) was incised and its mucosa was exposed. A new blade was used for scraping the mucosa of the teat cistern, whilst another one was used to scrape the mucosa of the teat duct. In ewes of Groups A, B, C and $\mathrm{E}$, an electronic cutimeter was used to measure $2 \mathrm{~mm}$ from the teat orifice, in order to determine the precise site within the teat, in which the inoculum had been deposited. Then, the mammary glands were dissected and samples were obtained for bacteriological and histological examination, as described before [21]. Scrapings from each of the two sites sampled in each teat, as well as tissue samples for bacteriological examination were plated onto Columbia blood agar; the media were incubated aerobically at $37^{\circ} \mathrm{C}$ for up to $72 \mathrm{~h}$. Throughout this study, all bacteria isolated were identified by using conventional techniques [6].

Longitudinal sections, involving all the structures of the teat, were taken out for histological examination. Tissue samples were fixed in 10\% neutral-buffered formalin and embedded in paraffin wax, using conventional techniques. Haematoxylin and eosin (HE) standard staining procedures were performed for histopathological studies.

\subsection{Data management and analysis}

The proportions of challenges, which resulted in clinical mastitis, were compared by using the Fisher-Exact test. Initially, the outcome in challenged teats was compared to that of the controlateral. Subsequently, the results of the ewes in Experiments I or II were compared against those of the control ewes. Finally, the test was used to compare the results of the ewes in Experiments I or II against those obtained in ewes that had been challenged by using the same method, but had clinically healthy teats, in a previous study [45]; these animals had been treated in the precise way as control animals in the current study. Statistical significance was defined as $P<0.05$.

One-sided $97.5 \%$ confidence limits of the probability of a ewe developing clinical mastitis were calculated for Experiment I, Experiment II and control ewes. The animals euthanised earlier than $12 \mathrm{~h}$ were not taken into account in this calculation.

In each inoculated teat, the number of sampling sites from which bacteria had been isolated during the post-mortem examination (i.e. teat duct, teat cistern, mammary parenchyma) was considered as a bacterial isolation score; therefore, the scores ranged from "0" (no bacteria isolated from any of the three sampling sites) to " 3 " (bacteria isolated from all three sites). Then, the mean score for Groups A to D and Groups E to F 
was calculated for each day when the ewes were euthanised, and plotted against time after challenge.

\section{RESULTS}

\subsection{Pre-inoculation examinations}

In experiment I, orf lesions in the teats were mild with scabs; they were approximately $1 \mathrm{~mm}$ in diameter and present in two to three sites near the orifice in each teat. Papilloma lesions in the teats, were nodular, proliferative, but not umbilicate, and 0.5 to $1 \mathrm{~cm}$ in diameter, three to five in each teat, at the middle and near the orifice of the teat. Lesions were present in both teats of each experimental animal. Apart from these, no other pathological findings (e.g. hardness, nodules etc.) were detected in the mammary glands or the teats of the ewes.

In experiment II, the mammary glands and the teats of all ewes were clinically healthy during the period from lambing to chapping. The teats were soft with no external abnormalities. After immersion into the $\mathrm{NaOH}$ solution, all teats became chapped to score " 2 " to " 3 ".

The mammary glands and the teats of all control ewes were clinically healthy during the period from lambing to inoculation. The teats were soft with no external abnormalities.

A variety of bacteria was isolated from all teat skin swabs; the majority of the organisms was coagulase-negative Staphylococcus spp., but other bacteria (e.g. Bacillus spp., Acinetobacter spp.) were also isolated. M. haemolytica was recovered sporadically after the 10th day post-lambing ( $1 \mathrm{~A}$ ewe, $2 \mathrm{C}$ ewes, $2 \mathrm{E}$ ewes, $1 \mathrm{~F}$ ewe). No bacteria were isolated from any catheter or milk samples.

In Experiment I, as well as in Experiment II before chapping of teat skin, the CMT was always negative; in Giemsa-stained secretion films, no leucocytes were observed. After chapping of teat skin (Experiment II), the CMT became positive (score " 1 ") and leucocytes (80-90\% neutrophils, 10-20\% macrophages) were observed in Giemsastained secretion films. In samples obtained from control ewes, the CMT was always negative; in Giemsa-stained secretion films, no leucocytes were observed.

\subsection{Clinical, bacteriological and cytological findings}

\subsubsection{Deposition of M. haemolytica into the teat duct of ewes with orf or papilloma virus (Experiment I)}

All ewes in Group A (except the one euthanised $2 \mathrm{~h}$ post-inoculation) became systemically ill and developed clinical mastitis. By $12 \mathrm{~h}$ after challenge, rectal temperature up to $41.3{ }^{\circ} \mathrm{C}$, indifference, lameness and ruminal stasis were evident. The secretion was found to be abnormal (serous or sero-sanguinous, with flakes) $5 \mathrm{~h}$ after challenge; abnormal mammary signs (enlarged, hot, hard and painful mammary gland, with reddened udder skin) were initially seen $12 \mathrm{~h}$ after challenge. No abnormalities, other than the viral ones, were recorded in the teats.

All ewes in Group B (except the one euthanised $5 \mathrm{~h}$ post-inoculation) developed clinical mastitis. The secretion was found to be abnormal (containing flakes and later becoming purulent); abnormal mammary signs (enlarged, hot, hard and painful mammary gland) were seen $24 \mathrm{~h}$ after challenge. No abnormalities, other than the viral ones, were recorded in the teats.

Inoculated teats were significantly more likely to develop clinical mastitis than their own within-ewe controls $(P<0.001)$. There was also a significant difference in the development of clinical mastitis, between inoculated and control ewes $(P=0.005)$; when the ewes of the previous study were also included as controls, the significance became $P<0.001$. The "best-estimate" of the probability of a challenged ewe with orf or papilloma lesions developing clinical 
Table III. Sequential clinical, bacteriological and CMT findings in samples from ewes, with teats inoculated with $M$. haemolytica.

\begin{tabular}{|c|c|c|c|c|c|c|c|c|}
\hline & \multicolumn{8}{|c|}{ Time after challenge } \\
\hline & $2 \mathrm{~h}$ & $5 \mathrm{~h}$ & $12 \mathrm{~h}$ & $18 \mathrm{~h}$ & $1 \mathrm{~d}$ & $2 \mathrm{~d}$ & $3 \mathrm{~d}$ & $4 \mathrm{~d}$ \\
\hline \multicolumn{9}{|l|}{ Group A } \\
\hline Clinical mammary findings ${ }^{\mathrm{a}}$ & $0 / 5^{\mathrm{b}}$ & $4 / 4$ & $3 / 3$ & $2 / 2$ & $2 / 2$ & $1 / 1$ & $1 / 1$ & - \\
\hline Bacteriological findings (secretion) & $5 / 5$ & $4 / 4$ & $3 / 3$ & $2 / 2$ & $2 / 2$ & $1 / 1$ & $1 / 1$ & - \\
\hline CMT results & $0 / 5$ & $4 / 4$ & $3 / 3$ & $2 / 2$ & $2 / 2$ & $1 / 1$ & $1 / 1$ & - \\
\hline \multicolumn{9}{|l|}{ Group B } \\
\hline Clinical mammary findings & $0 / 3$ & $0 / 3$ & $0 / 2$ & $0 / 2$ & $2 / 2$ & $1 / 1$ & $1 / 1$ & - \\
\hline Bacteriological findings (secretion) & $3 / 3$ & $3 / 3$ & $2 / 2$ & $2 / 2$ & $2 / 2$ & $1 / 1$ & $1 / 1$ & - \\
\hline CMT results & $0 / 3$ & $3 / 3$ & $2 / 2$ & $2 / 2$ & $2 / 2$ & $1 / 1$ & $1 / 1$ & - \\
\hline \multicolumn{9}{|l|}{ Group C } \\
\hline Clinical mammary findings & $0 / 7$ & $6 / 6$ & $5 / 5$ & $4 / 4$ & $4 / 4$ & $3 / 3$ & $2 / 2$ & $1 / 1$ \\
\hline Bacteriological findings (secretion) & $7 / 7$ & $6 / 6$ & $5 / 5$ & $4 / 4$ & $4 / 4$ & $3 / 3$ & $2 / 2$ & $1 / 1$ \\
\hline CMT results & $7 / 7$ & $6 / 6$ & $5 / 5$ & $4 / 4$ & $4 / 4$ & $3 / 3$ & $2 / 2$ & $1 / 1$ \\
\hline \multicolumn{9}{|l|}{ Group D } \\
\hline Clinical mammary findings & $0 / 4$ & $0 / 4$ & $0 / 4$ & $0 / 4$ & $3 / 4$ & $3 / 3$ & $2 / 2$ & $1 / 1$ \\
\hline Bacteriological findings (secretion) & - & - & - & $4 / 4$ & $4 / 4$ & $3 / 3$ & $2 / 2$ & $1 / 1$ \\
\hline Bacteriological findings (teat catheter) & - & - & - & $4 / 4$ & $4 / 4$ & $3 / 3$ & $2 / 2$ & $1 / 1$ \\
\hline Bacteriological findings (skin swab) & $4 / 4$ & $4 / 4$ & $4 / 4$ & $4 / 4$ & $4 / 4$ & $3 / 3$ & $2 / 2$ & $1^{\mathrm{c} / 1}$ \\
\hline CMT results & - & - & - & $4 / 4$ & $4 / 4$ & $3 / 3$ & $2 / 2$ & $1 / 1$ \\
\hline \multicolumn{9}{|l|}{ Group E } \\
\hline Clinical mammary findings ${ }^{\mathrm{a}}$ & $0 / 5$ & $0 / 5$ & $0 / 5$ & $0 / 4$ & $0 / 4$ & $0 / 3$ & $0 / 2$ & $0 / 1$ \\
\hline Bacteriological findings (secretion) & $0 / 5$ & $0 / 5$ & $2 / 5$ & $4 / 4$ & $4 / 4$ & $3 / 3$ & $2 / 2$ & $1 / 1$ \\
\hline CMT results & $0 / 5$ & $0 / 5$ & $4 / 5$ & $4 / 4$ & $4 / 4$ & $3 / 3$ & $2 / 2$ & $1 / 1$ \\
\hline \multicolumn{9}{|l|}{ Group F } \\
\hline Clinical mammary findings & $0 / 2$ & $0 / 2$ & $0 / 2$ & $0 / 2$ & $0 / 2$ & $0 / 2$ & $0 / 1$ & $0 / 1$ \\
\hline Bacteriological findings (secretion) & - & - & - & $0 / 2$ & $0 / 2$ & $1 / 2$ & $1 / 1$ & $1 / 1$ \\
\hline Bacteriological findings (teat catheter) & - & - & - & $0 / 2$ & $0 / 2$ & $2 / 2$ & $1 / 1$ & $1 / 1$ \\
\hline Bacteriological findings (skin swab) & $2 / 2$ & $2 / 2$ & $2 / 2$ & $2 / 2$ & $2 / 2$ & $2 / 2$ & $1 / 1$ & $1 / 1$ \\
\hline CMT results & - & - & - & $0 / 2$ & $2 / 2$ & $2 / 2$ & $1 / 1$ & $1 / 1$ \\
\hline
\end{tabular}

${ }^{a}$ Includes finding of abnormal secretion.

$\mathrm{b} \mathrm{n} / \mathrm{m}$ : positive results out of total animals sampled.

${ }^{c}$ Bacteria other than M. haemolytica, isolated as well.

mastitis, was $100 \%$ and the $97.5 \%$ confidence interval was $54.1 \%$ to $100 \%$.

$M$. haemolytica was consistently isolated from all secretion samples obtained after challenge (Tab. III). In all ewes, the CMT increased ( $\geq$ " 2 ") $5 \mathrm{~h}$ after challenge. In Giemsa-stained secretion films, rods were seen $2 \mathrm{~h}$ after challenge and subsequently. No macrophages were seen in secretion samples from the animals of either group; the majority of the cells were lymphocytes (70$80 \%$ ), with some neutrophils also being present (20-30\%).

No clinical signs were observed in any control gland or teat (apart from the viral lesions). No bacteria were recovered from any sample obtained from these. The CMT was always negative; in Giemsa-stained secretion films, no leucocytes were observed. 


\subsubsection{Deposition of M. haemolytica into the teat duct or the teat skin of ewes, with artificially induced skin chapping (Experiment II)}

All ewes in Group C (except the one euthanised $2 \mathrm{~h}$ post-inoculation) became systemically ill and developed clinical mastitis. By $12 \mathrm{~h}$ after challenge, rectal temperature up to $42.1^{\circ} \mathrm{C}$, indifference, lameness and ruminal stasis were evident. The secretion was found to be abnormal (serous, sero-sanguinous or purulent, with flakes or clots) $5 \mathrm{~h}$ after challenge; abnormal mammary signs (enlarged, hot, hard and painful mammary gland, with reddened udder skin) were seen $5 \mathrm{~h}$ after challenge. The inoculated teats were hot and hard and expression of milk was difficult.

All ewes in Group D (except the one euthanised $24 \mathrm{~h}$ after challenge) became ill and developed clinical signs of mastitis. By $2 \mathrm{~d}$ after challenge, rectal temperature increased up to $42.0^{\circ} \mathrm{C}$ and there was indifference; lameness and ruminal stasis were evident. The secretion was sero-sanguinous $24 \mathrm{~h}$ after challenge; abnormal mammary signs were as above and seen $24 \mathrm{~h}$ after challenge.

Inoculated teats were significantly more likely to develop clinical mastitis than their own within-ewe controls (Group C: $P<$ 0.001 , Group D: $P=0.03$ ). There was also a significant difference in the development of clinical mastitis, between inoculated and control ewes (Group C: $P=0.005$, Group D: $P=0.07)$; when the ewes of the previous study were also included as controls, the significance became $P<0.001$ for Group C and $P=0.002$ for Group D. The "best-estimate" of the probability of a ewe with chapping lesions in the teats developing clinical mastitis, was $100 \%$ and the $97.5 \%$ confidence interval was $63.1 \%$ to $100 \%$.

M. haemolytica was consistently isolated from all secretion samples obtained after challenge. The organism was also isolated from all catheter samples, as well as from all skin swabs (Group D) (Tab. III).
The CMT increased ( $\geq$ "2") $5 \mathrm{~h}$ (Group C) or $18 \mathrm{~h}$ (Group D) after challenge. In Giemsa-stained milk films, rods were seen $2 \mathrm{~h}$ (Group C) or $18 \mathrm{~h}$ (Group D) after challenge and subsequently. In the early stages after challenge (up to $5 \mathrm{~h}$ ), the cells observed in secretion films from Group C ewes were neutrophils (70-90\%) and macrophages (10-30\%); subsequently (especially $24 \mathrm{~h}$ after challenge and thereafter), the predominant cells were neutrophils (40-60\%) and lymphocytes $(40-60 \%)$, with some macrophages $(<10 \%)$ also present. The cells observed in secretion films from Group D ewes were neutrophils (70-90\%) and macrophages (10-30\%) up to $24 \mathrm{~h}$ after challenge, with neutrophils (40-60\%), lymphocytes $(40-60 \%)$ and some macrophages $(<10 \%)$ subsequently.

In one Group C ewe, clinical mastitis was seen in the control gland $3 \mathrm{~d}$ after challenge; the control teat, apart from the chapped lesions, appeared normal. M. haemolytica was isolated from the secretion $2 \mathrm{~d}$ after challenge; the CMT increased (score " 1 "" 2 ") and in Giemsa-stained secretion films, neutrophils were the most numerous cells observed.

Control teats of all other ewes remained chapped to a score "4"; no clinical findings characteristic of mastitis were observed. No bacteria were recovered from any secretion or intra-teat catheter sample obtained from the control mammary gland or teat of the experimental ewes. A mixed culture of bacteria (coagulase-negative Staphylococcus spp., Bacillus spp., etc.), but no M. haemolytica, was isolated after chapping from skin swab samples. The CMT was consistently found to be mildly positive (score "1") in secretion samples, whilst in Giemsa-stained secretion films, neutrophils were the predominant (> 80\%) cell type observed.

Details of the above results are given in Table III.

\subsubsection{Controls}

None of the control ewes became ill or developed clinical mastitis. Ewes maintained 
their appetite, and their rectal temperature never exceeded $39.8^{\circ} \mathrm{C}$. No changes in mammary secretion were evident; the mammary glands and the teats were soft, with no abnormalities. The ewes were milked with ease.

M. haemolytica was isolated from $51 \%$ of secretion samples obtained after challenge, as well as from $40 \%$ of catheter samples and all skin swabs (Group F). The CMT increased ( $\geq$ " 2 ") $1 \mathrm{~d}$ (Group E) or $4 \mathrm{~d}$ (Group F) after challenge. Leucocytes were seen in Giemsa-stained secretion films. In samples from Group E ewes, up to $2 \mathrm{~d}$ after challenge, the great majority $(\geq 80 \%)$ of leucocytes consisted of neutrophils, which subsequently decreased (50-60\%), whilst macrophages and lymphocytes became more prominent (5-35\% and 10-30\%, respectively). In samples from Group F ewes, the great majority ( $\geq 85 \%$ ) of leucocytes consisted of neutrophils.

\subsection{Pathological findings}

Measurement of the length of the internal teat structures after dissection of the teats of ewes of Groups A, B, C and E, showed that the inoculum had always been deposited within the teat duct.

$M$. haemolytica was consistently isolated in pure culture from all tissue samples obtained from ewes with teat lesions (except the samples from the mammary parenchyma of Group A and Group C ewes euthanised $2 \mathrm{~h}$ after challenge). The organism was also isolated in pure culture from $71 \%$ of tissue samples (mainly from teat duct and teat cistern) obtained from the control ewes (Tab. IV). Mean bacterial isolation scores for (i) Groups A to D and (ii) Groups E to $\mathrm{F}$ are depicted in Figure 1, plotted against time.

\subsubsection{Group A and Group B}

The principal macroscopic lesions inside the challenged teats were folds, hyperaemia and thickness of the mucosa. Histologically, we recorded principally extensive subepithelial neutrophilic infiltration evident from $5 \mathrm{~h}$ after challenge and subsequently; other
Table IV. Post-mortem isolation of M. haemolytica from the teats of ewes inoculated with the organism.

\begin{tabular}{|c|c|c|c|c|c|c|c|}
\hline \multirow[b]{2}{*}{ Group } & \multicolumn{7}{|c|}{ Time when ewe was euthanised } \\
\hline & $2 \mathrm{~h}$ & $5 \mathrm{~h}$ & $12 \mathrm{~h}$ & $1 \mathrm{~d}$ & $2 \mathrm{~d}$ & $3 \mathrm{~d}$ & $4 \mathrm{~d}$ \\
\hline Group A & & & & & & & \\
\hline Teat duct & + & + & + & + & & + & \\
\hline Teat cistern & + & + & + & + & & + & \\
\hline $\begin{array}{l}\text { Mammary } \\
\text { parenchyma }\end{array}$ & - & + & + & + & & + & \\
\hline Group B & & & & & & & \\
\hline Teat duct & & + & & + & & + & \\
\hline Teat cistern & & + & & + & & + & \\
\hline $\begin{array}{l}\text { Mammary } \\
\text { parenchyma }\end{array}$ & & + & & + & & + & \\
\hline Group C & & & & & & & \\
\hline Teat duct & + & + & + & + & + & + & + \\
\hline Teat cistern & + & + & + & + & + & + & + \\
\hline $\begin{array}{l}\text { Mammary } \\
\text { parenchyma }\end{array}$ & - & + & + & + & + & + & + \\
\hline Group D & & & & & & & \\
\hline Teat duct & & & & + & + & + & + \\
\hline Teat cistern & & & & + & + & + & + \\
\hline $\begin{array}{l}\text { Mammary } \\
\text { parenchyma }\end{array}$ & & & & + & + & + & + \\
\hline Group E & & & & & & & \\
\hline Teat duct & & & + & + & + & + & + \\
\hline Teat cistern & & & - & - & + & + & + \\
\hline $\begin{array}{l}\text { Mammary } \\
\text { parenchyma }\end{array}$ & & & - & - & - & - & + \\
\hline Group F & & & & & & & \\
\hline Teat duct & & & & & + & & + \\
\hline Teat cistern & & & & & - & & + \\
\hline $\begin{array}{l}\text { Mammary } \\
\text { parenchyma }\end{array}$ & & & & & - & & - \\
\hline
\end{tabular}

findings included the presence of lymphocytes and plasma cells, with exocytosis through the epithelium and into the lumen, lysis of neutrophils and destruction of epithelial cells (Fig. 2a). In inoculated teats of Group B ewes, damage to the teat epidermis and accumulation of lymphocytes and plasma cells were also observed.

Macroscopic lesions in the mammary parenchyma were apparent $12 \mathrm{~h}$ after challenge and subsequently; the gland was 
Mean Bacterial Isolation Score: Groups A to D Vs. Groups E to F

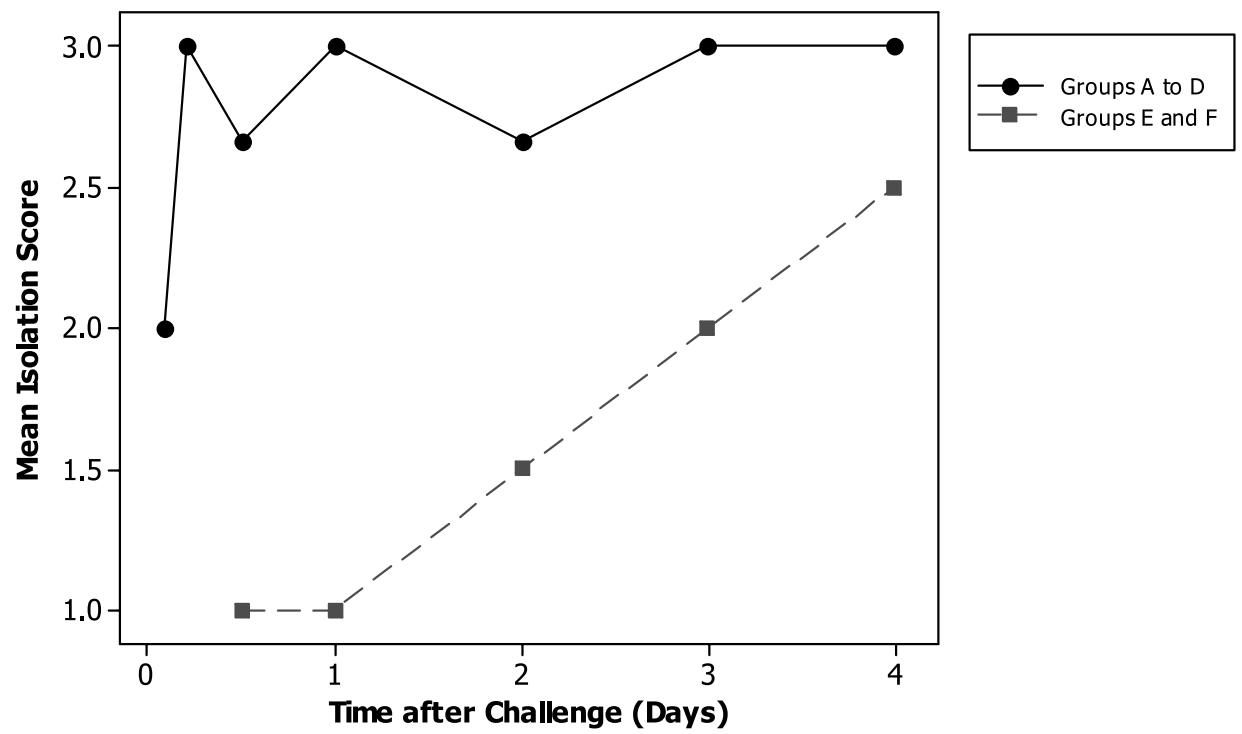

Figure 1. Results of bacterial isolation scores from samples obtained during the post-mortem examination of inoculated teats.

enlarged, with subcutaneous oedema and sanguineous fluid exuding from sections of the reddened parenchyma; the supramammary lymph nodes were enlarged and oedematous. Histologically, the salient feature was conspicuous neutrophilic infiltration, which became evident $5 \mathrm{~h}$ after challenge; other features were extravasation, intra-alveolar live and exhausted neutrophils, destruction of epithelial cells, alveolar destruction, lymphocytic infiltration and haemorrhages, which were observed from $12 \mathrm{~h}$ after challenge and subsequently.

Control teats appeared histologically normal, with no lymphoid tissue observed at the border between the teat duct and teat cistern. No pathological findings were evident in the parenchyma of the control mammary glands.

\subsubsection{Group C and Group D}

Macroscopic lesions inside the teat were folds, hyperaemia and thickness. Histopathological findings were first observed $5 \mathrm{~h}$
(Group C) or $24 \mathrm{~h}$ (Group D) after challenge, when sparse scattered lymphocytes were observed in the teat cistern and a small number of neutrophils in the teat duct. Subsequently, an increased number of neutrophils was seen sub-epithelially in the teat cistern and teat duct, whilst lymphocytes were present at the border of the teat ductteat cistern. With progression of time, the number of leucocytes decreased, although their proportion and distribution in tissues was similar to earlier time-points. Accumulation of plasma cells and subepithelial haemorrhages were also evident. In all teats studied (ewes of both groups), a conspicuous area of lymphoid tissue - lymphocytes and plasma cells, including a germinal centre-was observed at the border between the teat duct and teat cistern (Fig. 2b). In the skin of all teats studied (ewes of both groups), erosion and ulceration with the presence of sero-cellular crusting and leucocytic accumulation, were evident; however, these lesions did not extend into the teat duct or cistern (Fig. 3); their maximal 

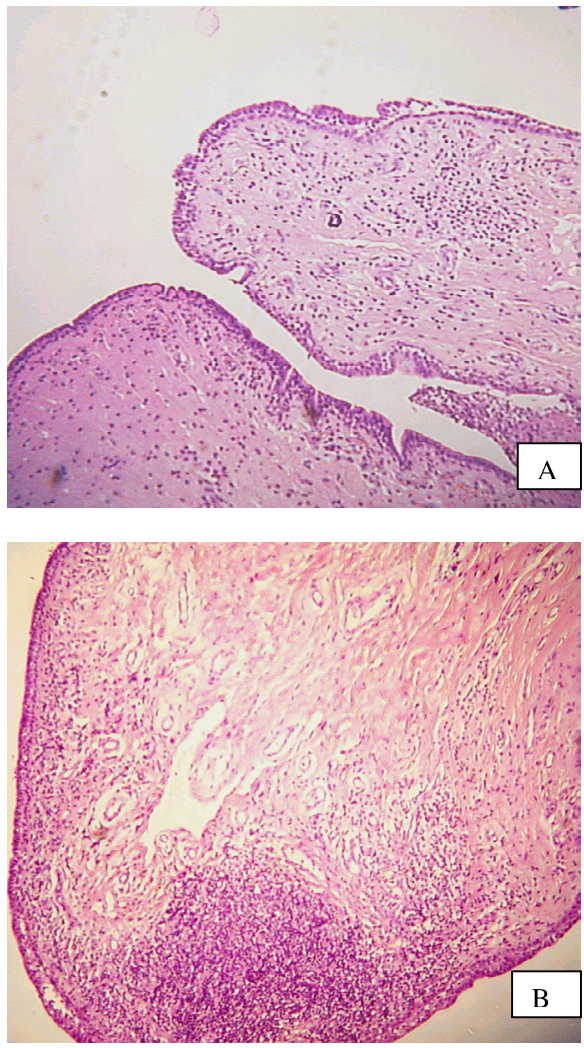

Figure 2. (A) Area between the teat duct-teat cistern in a ewe with lesions of orf in the teat, which was challenged into the teat duct with $M$. haemolytica; absence of lymphoid tissue (Experiment I, animal euthanised $12 \mathrm{~h}$ after challenge) (low magnification $5 \times$ objective, photograph taken on a Zeiss photomicroscope III). (B) Area between the teat duct-teat cistern in a ewe with chapping lesions in the teat, which was immersed into a $M$. haemolytica broth culture; presence of hyperplastic lymphoid tissue consisting of lymphocytes and plasma cells (Experiment II, animal euthanised $2 \mathrm{~d}$ after immersion into the broth culture) (low magnification $5 \times$ objective, photograph taken on a Zeiss photomicroscope III). A color version of this figure is available at www.edpsciences.org.

estimated depth was $1.5 \mathrm{~mm}$ and the underlying tissues were unremarkable. Additionally in the teat skin of Group D ewes, dense bacterial accumulations were present on the teat epidermis.

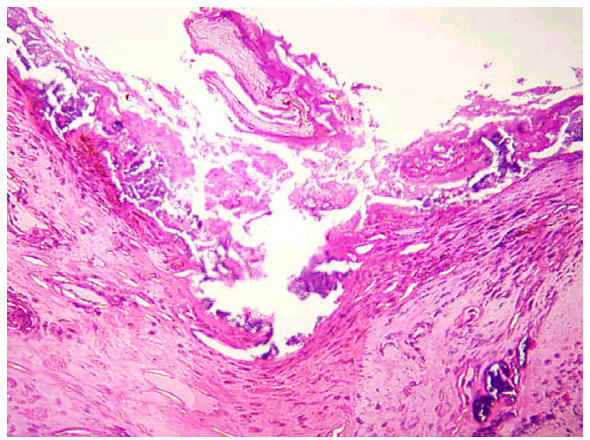

Figure 3. Erosion and ulceration with the presence of sero-cellular crusting in the skin of a chapped teat; the lesions do not extend into the teat duct (Experiment II, animal euthanised $5 \mathrm{~d}$ after skin chapping) (low magnification $10 x$ objective, photograph taken on a Zeiss photomicroscope III). A color version of this figure is available at www.edpsciences.org.

Macroscopic lesions in the mammary parenchyma included subcutaneous oedema, the presence of sanguineous fluid from parenchymal sections, and enlargement and oedema of the supramammary lymph nodes. Histopathological findings (massive neutrophilic infiltration) were first evident $5 \mathrm{~h}$ after challenge; subsequently, extravasation, haemorrhages, lysis of neutrophils and destruction of alveoli, were evident, whilst in ewes euthanised $2 \mathrm{~d}$ after challenge and subsequently, the internal architecture of the parenchyma was destroyed. In one ewe (animal euthanised $3 \mathrm{~d}$ after challenge), foci ( $5 \mathrm{~mm}$ in diameter) and petechiae were present on the heart.

The skin lesions described above were also present on the control teats; an area of hyperplastic lymphoid tissue was also observed in these teats. Apart from these, no other macroscopic or histological abnormalities were evident in the teats or the mammary parenchyma of the control mammary glands.

\subsubsection{Controls}

No pathological findings were evident in the control teats or mammary glands. 
Macroscopically, the teat of control ewes (Groups E and F) appeared normal with an apparently smooth internal lining; the teat duct and the teat cistern were clearly distinguished as two different anatomical structures. In Group E ewes, the salient histopathological finding was subepithelial leucocytic infiltration prominent at the border between the teat duct-teat cistern, observed $1 \mathrm{~d}$ after challenge and subsequently. In Group F ewes, the leucocytic infiltration was evident at the end of the teat duct in the ewes. An area of hyperplastic lymphoid tissue consisting of lymphocytes and plasma cells was observed at the border between the teat duct-teat cistern of all ewes.

\section{DISCUSSION}

In a previous experimental study of ovine mastitis associated with $M$. haemolytica [45], we inoculated two strains of the organism around or into healthy teats of ewes; the results indicated the significant protective role of healthy teats of ewes against the invading organism. One of those strains (VSM08L) was used in the current work. Although this isolate had been isolated from the teat duct of a healthy ewe, it caused clinical mastitis after direct intrammamary challenge into teats with lesions; it also caused subclinical mastitis 24 to $48 \mathrm{~h}$ after deposition inside clinically healthy teats.

In the present study, we investigated whether teats with natural or experimentally inflicted lesions would afford the same protection as healthy ones. In direct contrast to the results of inoculation of the organism into healthy teats, ewes with orf teat lesions, with papilloma teat lesions or with chapped teats developed clinical mastitis soon after deposition of the same dose of the organism into the teat duct. Orf and papilloma lesions are two commonly encountered viral lesions in the teats of ewes, as reported in the literature $[13,68,71,73]$ or recorded in personal clinical observations. Chapping lesions may be the consequence of inappropriate milking practices ([9], Hemling ${ }^{1}$ ) or exposure to cold [11, 23] or windy weather [24]; they may also be initiated by milking practices and aggravated by environmental factors [26].

Although in cows an association between teat injuries and mastitis has been established [49, 50, 62], even if the lesions are minor [1], the situation in small ruminants is not clear. The majority of authors reported an association between mastitis and teat lesions ([4, 20, 31, 32, 58], Onash et al. $\left.{ }^{2}\right)$, which are usually manifested as an outbreak [5, 20, 58]; furthermore, Watt [71] and Reid [59] mentioned that a possible secondary effect of orf was mastitis of the affected ewes. Nevertheless, authors did not report such an association [2, 70]. To our knowledge however, no experimental findings regarding these hypotheses have been published. The present results provide clear evidence that teats with lesions do not protect the mammary gland effectively. There may be various mechanisms and pathways, which may either impair the defence mechanisms of the animal or enhance the virulence of the invading organisms.

The orf virus encodes a range of immuno-modulatory genes that interfere with host anti-virus immune and inflammatory effector mechanisms; the virus produces interleukin-10, which suppresses cytokine production by activated macrophages of the host animal, whilst the virus' Granulocyte Macrophage Colony-stimulating Factor (GM-CSF) inhibitory factor is a protein inhibiting the biological activity of GM-CSF and interleukin-2 [34]. In the mammary gland, the GM-CSF factor activates macrophages and neutrophils [33] and improves chemotactic action and peroxidase production from neutrophils [19], whilst interleukin-2 enhances the phagocytic ability of macrophages and participates in the initial immune response in the

\footnotetext{
${ }^{1}$ Hemling T.C., Teat condition: prevention and cure through teat dips, Proc. Brit. Mast. Conf., Brockworth, 2002, pp. 1-14.

${ }^{2}$ Onash H., Healy A.M., Brophy P.O. et al., A study of mastitis in sheep, Proc. Sheep Vet. Soc., 2003, p. 49.
} 
mammary gland $[18,66]$, therefore, playing a role in the defence mechanisms of the mammary gland.

Haig et al. [34] also reported that in tissues with orf lesions, macrophages were scarce. In the current study, no macrophages were observed in Giemsa-stained secretion films from ewes with orf or papilloma lesions. Since macrophages constitute the first line of defence of the mammary gland, it is possible that their absence facilitated the rapid ascent of bacteria to the mammary parenchyma and subsequent development of clinical mastitis.

The papilloma virus also has evolved various ways to prevent clearance by the host immune system [53], including subversion of the animal's immune response, e.g. by modulating the antigen presentation process, by inhibiting interleukin activity, or by down-regulating major histocompatibility complex-I on infected tissues. Affected animals may also show immunosuppression $[10,47]$. In cows, the virus may hinder the specific defence mechanisms of the mammary gland [26], thus allowing bacterial infections to result in mastitis [72]. The virus reduces the immunological response of the animal [69], e.g. by reducing the number of antigen-presenting cells in affected tissues [67]. Our work suggests that this may also be the case in the mammary gland of ewes.

As mentioned earlier, we have presented evidence for a lymphoid focus at the teat duct-teat cistern border and have suggested that it might play a protective role against invading microorganisms [45]. Collins et al. [15] and Hibbitt et al. [40] had indicated that in cows, a similar structure provided local mammary immune response, by producing lymphocytes and plasma cells and thus, was significant in the defence of the mammary gland. This structure was not seen in histological sections of teats from ewes with orf or papilloma lesions; we postulate that this was another cause of impaired defence functions of the teat cistern in these ewes. Thus, bacteria invading the mammary gland caused mastitis more readily. The finding of consistent and rapid development of clinical mastitis after deposition of the organisms in the teat duct or on the teat skin, lends support to this hypothesis, and confirms that viral lesions in the teat predispose ewes to mammary infections.

Additionally, the virulence of the invading organisms may have been enhanced. Burriel [12] associated orf infection in ewes with increased iron concentrations in their milk. Administration of iron was found to increase the susceptibility of the animals to $M$. haemolytica infection [3], likely due to increased toxin production from the organism [30]. Therefore, it may be inferred that the increased iron concentration in milk of ewes with orf contributed to the rapid bacterial multiplication and the increased leucotoxin production, which -coupled to the immunosuppressive effects of the virus on the host- resulted in the acute, severe clinical signs of mastitis.

The efficiency of teat defence mechanisms largely depends on the integrity of teat tissues; their impairment was found to lead to increased risk of intramammary infections $[35,36]$. Unhealthy teat skin has been associated with an increase in the incidence of mastitis [37], since a change in the teat skin condition could result in a higher contamination of the teat surface with mastitis pathogens, resulting in an increased rate of intramammary infections [55].

In cows, chapped or burned teats are believed to pose an increased risk for intramammary infections [48]. In cases of cold weather, an increased incidence of chapped teats has been reported [23], which has been further associated with a Staphylococcus aureus intramammary infection [23], likely because teat skin in poor condition allowed greater microbial colonisation than healthy skin [25]. In ewes, Leyshon [44] and Clark ${ }^{3}$ have reported that mastitis

\footnotetext{
${ }^{3}$ Clark R.G., Field observations on ovine mastitis, Proc. 2nd Semin. N. Z. Vet. Assoc. Sheep Soc., Palmerston North, 1972, pp. 47-54.
} 
was more prevalent in cold weather; this could have been the consequence of chapped teats.

Physicochemical changes occurring in chapped teat skin, may contribute to the increased susceptibility of the mammary gland. In the epidermis, the process of drying decreases lipid content which contains antibacterial fatty acids, bacteriostatic salts and proteins, as well as immunoglobulins [51]. Additionally, the reduced hydration of chapped skin, alters skin microflora, consequently decreasing resistance to bacterial colonisation [22]. In our experiments, after chapping and immersion of the teat into a culture broth, $M$. haemolytica was isolated in pure culture and heavy growth from skin swabs, thus confirming the above observations. Lastly, chapping removes the acid mantle and increases teat surface area, due to excoriations and fissuring, thus providing additional surface for bacterial attachment [64]. In the histological sections of teats from Group D ewes, extensive bacterial accumulations were present on the external teat epidermal surface, potentially enhancing microbial availability close to the teat duct; similar findings were not observed in sections of teats from Group $\mathrm{F}$ ewes. Scott and Jones [63] isolated the organism from the teat skin of suckling ewes, but not from that of pregnant ewes or ewes after weaning of their lambs. Subsequently, Jones and Watkins [43] suggested that the organism might originate from the nares, mouth and tonsils of lambs sucking the affected ewe. One may therefore postulate, that in cases of cold weather, when neonates suck the nipples of their dams more often $[60,65]$ or when teats might become chapped [11,23], sucking by lambs contributes to the transfer of M. haemolytica to teat skin; subsequently, the organism might easily gain entry into the teat duct and cause mastitis, as corroborated by the results of our experiment. This hypothesis would explain the findings of Leyshon [44] and Clark ${ }^{3}$.
Cheville [14] mentioned that in damaged skin, there was reduced responsiveness and defective chemotaxis of neutrophils, which might allow bacterial invasion and consequent local or systemic infection. Furthermore, neutrophils cannot withstand the low $\mathrm{pH}$ and high temperature in inflamed tissues [38, 42]. Finally, exposure to trauma or cold causes degranulation and lysis of mast cells [39], which play a role in enhancing the early stages of inflammation [29]; this would subsequently affect the inflammatory defence pathway. One may thus postulate that similar events have taken place in the chapped teats, hindering the normal defencive process of the mammary gland.

Our experimental findings allied to the field observations reported by previous authors, suggest that teat lesions appear to adversely affect mammary defence mechanisms, thus speeding up the process of infection and making it more severe. Therefore preservation of healthy teats is vitally important in maintaining the natural defences against invading organisms and in contributing to the prevention of mastitis in ewes.

\section{ACKNOWLEDGEMENTS}

The work described in this paper has been supported by a grant from the Greek Ministry of Education (EPEAEK - HRAKLEITOS project).

Special thanks are given to Dr Harriet Brooks (Royal Veterinary College, London) for substantial help with interpretation of histological findings and constructive comments on the manuscript. Also, thanks to Dr Billinis for his help with the laboratory confirmation of the viral infections of the teats.

\section{REFERENCES}

[1] Agger J.F., Willeberg P., Epidemiology of teat lesions in a dairy herd. 2. Associations with subclinical mastitis, Nord. Vet. Med. 38 (1986) 220-232.

[2] Al-Majali A.M., Jawabreh S., Period prevalence and aetiology of subclinical mastitis in Awassi sheep in southern Jordan, Small Rumin. Res. 47 (2003) 243-248. 
[3] Al-Sultan I.I., Aitken I.D., Promotion of Pasteurella haemolytica infection in mice by iron, Res. Vet. Sci. 36 (1984) 385-386.

[4] Ameh J.A., Tari I.S., Observations on the prevalence of caprine mastitis in relation to predisposing factors in Maiduguri, Small Rumin. Res. 35 (2000) 1-5.

[5] Anon., Skin diseases, Vet. Rec. 152 (2003) 581.

[6] Barrow G.I., Feltham R.K.A., Manual for the Identification of Medical Bacteria, 3rd edition, Cambridge University Press, Cambridge, 1993.

[7] Bergonier D., Berthelot X., New advances in epizootiology and control of ewe mastitis, Livest. Prod. Sci. 79 (2003) 1-16.

[8] Bergonier D., De Cremoux R., Rupp R., Lagriffoul G., Berthelot X., Mastitis of dairy small ruminants, Vet. Res. 34 (2003) 689716.

[9] Bramley A.J., Mastitis and machine milking, in: Bramley A.J., Dodd F.H., Mein G.A., Bramley J.A. (Eds.), Machine Milking and Lactation, Insight Books, Newbury, 1992, pp. 343-372.

[10] Bredal W.P., Thoresen S.I., Rimstad E., Aleksandersen M., Nafstad P.H.J., Diagnosis and clinical course of canine oral papillomavirus infection, J. Small Anim. Pract. 37 (1996) 138-142.

[11] Burmeister J.E., Fox L.K., Hancock D.D., Gay C.C., Gay J.M., Parish S.M., Tyler J.W., Survey of dairy managers in the Pacific Northwest identifying factors associated with teat chapping, J. Dairy Sci. 78 (1995) 2073-2082.

[12] Burriel A.R., Udder orf infection and its role in ovine clinical mastitis caused by Pasteurella haemolytica, J. Trace Elem. Med. Biol. 11 (1997) 28-31.

[13] Buttner M., Rziha H.J., Parapoxviruses: from the lesion to the viral genome, J. Vet. Med. B 49 (2002) 7-16.

[14] Cheville N.F., Ultrastructural pathology: an introduction to interpretation, Iowa State University Press, Ames, 1994.

[15] Collins R.A., Parsons K.R., Bland A.P., Antibody containing cells and specialized epithelial cells in the bovine teat, Res. Vet. Sci. 41 (1986) 50-55.

[16] Collins R.A., Parsons K.R., Field T.R., Bramley A.J., Histochemical localization and possible antibacterial role of xanthine oxidase in the bovine mammary gland, J. Dairy Res. 55 (1988) 25-32.
[17] Craven N., Williams M.R., Defences of the bovine mammary gland against infection and prospects for their enhancement, Vet. Immunol. Immunopathol. 10 (1985) 71-127.

[18] Daley M., Coyle P., Williams T.J., Furda G., Dougherty R., Hayes P.W., Staphylococcus aureus mastitis: pathogenesis and treatment with bovine interleukin-1 and interleukin-2, J. Dairy Sci. 74 (1991) 4413-4424.

[19] Daley M., Williams T., Coyle P., Furda G., Dougherty R., Hayes P., Prevention and therapy of Staphylococcus aureus infections with recombinant cytokines, Cytokine 5 (1993) 276-283.

[20] Doherty M.L., Bassett H.P., Staphylococcal dermatitis in sheep, Vet. Rec. 124 (1989) 470.

[21] El-Masannat E.T.S., Jones J.E.T., Scott M.J., The experimental production of mastitis in sheep by intramammary inoculation of Pasteurella haemolytica, J. Comp. Pathol. 105 (1991) 455-465.

[22] Fox L.K., Cumming M.S., Relationship between thickness, chapping and Staphylococcus aureus colonization of bovine teat tissue, J. Dairy Res. 63 (1995) 369-375.

[23] Fox L.K., Hancock D.D., Effects of segregation on prevention of intramammary infections by Staphylococcus aureus, J. Dairy Sci. 72 (1989) 540-544.

[24] Fox L.K., Norell R.J., Staphylococcus aureus colonization of teat skin as affected by postmilking teat treatment when exposed to cold and windy conditions, J. Dairy Sci. 77 (1994) 2281-2288.

[25] Fox L.K., Nagy J.A., Hillers J.K., Cronrath J.D., Ratkowsky D.A., Effects of postmilking teat treatment on the colonization of Staphylococcus aureus on chapped teat skin, Am. J. Vet. Res. 52 (1991) 799-802.

[26] Francis P.G., Teat skin lesions and mastitis, Br. Vet. J. 140 (1984) 430-436.

[27] Fthenakis G.C., Prevalence and aetiology of subclinical mastitis in ewes of Southern Greece, Small Rumin. Res. 13 (1994) 293300.

[28] Fthenakis G.C., California Mastitis Test and Whiteside Test in diagnosis of subclinical mastitis of dairy ewes, Small Rumin. Res. 16 (1995) 271-276

[29] Galli S.J., Dvorak A.M., Dvorak H.F., Basophils and mast cells: morphologic insights into their biology, secretory patterns, and function, Prog. Allergy 34 (1984) 1-141. 
[30] Gentry M.J., Confer A.W., Weinberg E.D. Homer J.T., Cytotoxin (leucotoxin) production by Pasteurella haemolytica: requirement for an iron-containing compound, Am. J. Vet. Res. 47 (1986) 1919-1923.

[31] Gunning R.F., Bosworth P.A., Staphylococcal dermatitis involving the teats of lactating ewes, Vet. Rec. 124 (1989) 146-147.

[32] Gunning R.F., Davies C.H., Isolation of Pasteurella haemolytica from teat lesions in ewes, Vet. Rec. 125 (1989) 490.

[33] Haig D.M., Percival A., Mitchell J., Green I., Sargan D., The survival and growth of ovine afferent lymph dendritic cells in culture depends on tumour necrosis factor- and is enhanced by granulocyte-macrophage colony-stimulating factor but inhibited by interferon-, Vet. Immunol. Immunopathol. 45 (1995) 221-236.

[34] Haig D.M., Thomson J., McInnes C., McCaughan C., Imlach W., Mercer A., Fleming S., Orf virus immuno-modulation and the host immune response, Vet. Immunol. Immunopathol. 87 (2002) 395-399.

[35] Hamann J., Measurement of machine milking induced teat tissue reactions, Milchwissenschaft 40 (1985) 16-18.

[36] Hamann J., Factors for the genesis of bovine subclinical mastitis, Berl. Munch. Tierarztl. Wochenschr. 102 (1989) 342-346.

[37] Hamann J., Stimulation and teat tissue reaction, Kieler Milchw. Forsch. 44 (1992) 339347.

[38] Harlan J.M., Schwartz B.R., Reidy M.A., Schwartz S.M., Ochs H.D., Harker L.A., Activated neutrophils disrupt endothelial monolayer integrity by an oxygen radical-independent mechanism, Lab. Invest. 52 (1985) 141150.

[39] Henderson W.R., Chi E.Y., Klebanoff S.J., Eosinophil peroxidase-induced mast cell secretion, J. Exp. Med. 152 (1980) 265-279.

[40] Hibbitt K.G., Craven N., Batten E.H., Anatomy, physiology and immunology of the udder, in: Andrews A.H., Blowey R.H., Boyd H., Eddy R.G. (Eds.), Bovine Medicine: Diseases and Husbandry of Cattle, Blackwell, Oxford, 1996, pp. 273-278.

[41] Inoshima Y., Morooka A., Sentsui H., Detection and diagnosis of parapoxvirus by the polymerase chain reaction, J. Virol. Methods 84 (2000) 201-208.

[42] Jacques Y.V., Bainton D.F., Changes in pH within the phagocytic vacuoles of human neu- trophils and monocytes, Lab. Invest. 39 (1978) 179-185.

[43] Jones J.E.T., Watkins G.H, Mastitis and contagious agalactia, in: Martin W.B., Aitken I.D. (Eds.), Diseases of Sheep, 3rd edition, Blackwell, Oxford, 2000, pp. 75-80.

[44] Leyshon W.J., An examination of a number of cases of ovine mastitis, Vet. J. 85 (1929) 286300, 331-344.

[45] Mavrogianni V.S., Fthenakis G.C., Brooks H., Papaioannou N., Cripps P.J., Taitzoglou I., Brellou G., Saratsis P., The effects of inoculation of Mannheimia haemolytica into the teat of lactating ewes, Vet. Res. 36(2005) 13-25.

[46] Miles A.A., Misra J.S., The estimation of the bactericidal power of the blood, J. Hyg. Camb. 38 (1938) 732-749.

[47] Mill A.B., Campbell K.L., Concurrent hypothyroidism, IgM deficiency, impaired $\mathrm{T}$-cell mitogen response, and multifocal cutaneous squamous papillomas in a dog, Canine Pract. 17 (1992) 15-21.

[48] Neave F.K., Dodd F.H., Kingwill R.G., Westgarth D.R., Control of mastitis in the dairy herd by hygiene and management, J. Dairy Sci. 52 (1961) 696-706.

[49] Neijenhuis F., Barkema H.W., Hogeveen H., Noordhuizen J.P.T.M., Relationship between teat-end callosity and occurrence of clinical mastitis, J. Dairy Sci. 84 (2001) 2664-2672.

[50] Nitzig P., Rusch P., Berchtold M., Wesen, Diagnose und Behandlung von Schleimhautabrissen im Bereich des Strichkanals, Dtsch. Tierarztl. Wochenschr. 91 (1984) 219222.

[51] Noble W.C., Somerville D.A., Skin as a habitat, in: Noble W.C. (Ed.), Microbiology of Human Skin, Saunders, Philadelphia, 1974, pp. 3-78.

[52] Norcross N.L., Specific defence mechanisms of the udder, Flemish Vet. J. 62 (1991) 129139.

[53] O’Brien P.M., Campo M.S., Evasion of host immunity directed by papillomavirus encoded proteins, Virus Res. 8 (2002) 103-117.

[54] Paape M.J., Schultze W.D., Guidry A.J., Development of natural defence mechanisms, Kieler Milchw. Forsch. 37 (1985) 447-457.

[55] Pankey J.W., Eberhart R.J., Cumming A.L., Daggett R.J, Farnsworth R.J., McDuff C.K., Uptake of postmilking teat antisepsis, J. Dairy Sci. 67 (1984) 1336-1353. 
[56] Persson K., Inflammatory reactions in the teat and udder of the dry cow, Zentralbl. Veterinarmed. B 37 (1990) 599-610.

[57] Persson K., Colditz I.G., Flapper P., Franklin N.A.F. Seow H.F. Cytokine-induced inflammation in the ovine teat and udder, Vet. Immunol. Immunopathol. 53 (1996) 73-85.

[58] Quinney S., Davison N., Bebbington T., Severe teat lesions in a sheep flock, Vet. Rec. $152(2003) 696$.

[59] Reid H.W., Orf, in: Martin W.B., Aitken I.D. (Eds.), Diseases of Sheep, 2nd edition, Blackwell, Oxford, 1991, pp. 265-269.

[60] Reif M.H., Field T., Diego M., Differential sucking by neonates of depressed versus nondepressed mothers, Infant. Behav. Dev. 27 (2001) 465-476.

[61] Reiter B., Protective proteins in milk. Biological significance and exploitation, Bull. Int. Dairy Fed. 191 (1985) 1-35.

[62] Saloniemi H., Roine K., Field observations on the incidence of bovine clinical mastitis and teat diseases, Nord. Vet. Med. 43 (1981) 297305.

[63] Scott M.J., Jones J.E.T., The carriage of Pasteurella haemolytica in sheep and its transfer between ewes and lambs in relation to mastitis, J. Comp. Pathol. 118 (1998) 359-363.

[64] Sieber R.L., Farnsworth R.J., Differential diagnosis of bovine teat lesions, Vet. Clin. North Am. - Large A. 6 (1984) 313-321.

[65] Slee J., Springbett A., Early post-natal behaviour in lambs of ten breeds, Appl. Anim. Behav. Sci. 15 (1986) 229-240.
[66] Sordillo L.M., Weaver K.S., DeRosa D., Immunobiology of the mammary gland, J. Dairy Sci. 80 (1997) 1851-1865.

[67] Tay S.K., Jenkins D., Maddox P., Campion M., Singer A., Subpopulations of Langerhans cells in cervical intraepithelial neoplasia and human papillomavirus infection, Br. J. Obstet. Gynaecol. 94 (1987) 16-21.

[68] Uzal F.A., Latorraca A., Ghoddusi M., Horn M., Adamson M., Kelly W.R., Schenkel R., An apparent outbreak of cutaneous papillomatosis in Merino sheep in Patagonia, Argentina, Vet. Res. Commun. 24 (2000) 197-202.

[69] Yirrell D.L., Norval M., Reid H.W., Local epidermal viral infections: comparative aspects of vaccinia virus, herpes simplex virus and human papillomavirus in man and orf virus in sheep, FEMS Immunol. Med. Microbiol. 8 (1994) 1-12.

[70] Watkins G.H., Burriel A.R., Jones J.E.T., A field investigation of subclinical mastitis in sheep in southern England, Br. Vet. J. 147 (1991) 413-420.

[71] Watt J.A.A., Contagious pustular dermatitis, in: Martin W.B., Aitken I.D. (Eds.), Diseases of Sheep, Blackwell, Oxford, 1983, pp. 185188.

[72] William J.B., Kirubaharan J.J., Uthuman K.M., Kumanan K., Balachandran S., Survey on incidence and complications of bovine cutaneus papillomatosis, Indian Vet. J. 69 (1992) 843-844.

[73] Yeruham I., Perl S., Abraham A., Orf infection in four sheep flocks, Vet. J. 160 (2000) $74-76$. 